\title{
SEASONAL FLUCTUATION OF LACE BUG Stephanitis pyri (F) (HEMIPTERA: TINGIDAE) IN ERBIL-IRAQ
}

\author{
Sarkaut Hussein Muhammed \\ Dept. of Biology, College of Science, University of Salahaddein, Kurdistan Region-Iraq
}

(Received: April 25, 2021; Accepted for Publication: August 1, 2021)

\begin{abstract}
This investigation conducted during the two successive seasons 2012-2013 in orchards within Erbil city to follow seasonal fluctuation of Stephanitis pyri. S. pyri start appear in the first week of April and reached a peak level 13.90, 11.4 in third week of August for the two years respectively when the mean temperature was ranged $33-34{ }^{\circ} \mathrm{C}$ and R.H. $24-29 \%$. Correlation values for lace bug incidence with weather parameters showed that maximum and minimum RH had negative influence on lace bug population. The change in the level of infestation was due to difference in environmental temperature, relative humidity. Field investigation pointed out that the female's activity of $S$. pyri began during the period from $1^{\text {st }}$ week of April onward $4^{\text {th }}$ week of October through which it laid their eggs.
\end{abstract}

KEYWORDS: Lace bug, Pear tree, Seasonal Fluctuation, Stephanitis pyri

\section{INTRODUCTION}

$\mathbf{P}$ ears, grown in all temperate regions of the world, is one of the trees genus Pyrus that belongs to family Rosaceae. Several kinds of pear are valued for their edible fruit, while others are cultivated as shade trees (Silva, et al., 2014). For their suitable environmental, many fruit trees planted in Erbil among them Pear trees (RSO, 2008).

The lace bug Stephanitis pyri (F.) (Tingidae; Heteroptera) generally attack leaves of pome and other stone fruit trees from family Rosaceae in the Mediterranean countries (Önder and Lodos 1983; Barta \& Biben, 2016), causes serious losses of yield in pear trees and reduces its marketable value (Kivan \& Aysal, 2011; Hradil et al., 2013). Lace bug, S. pyri (F) was considered to be one of the main economics pests on pear trees (Muhammed, 1995; Şahin et al., 2009). Feeding of adults and nymphs on the underside of leaves lead to produce small chlorotic stippling on the upper leaf surface. Black or dark brown spotted appear characteristically on the lower surface of leaves due to lace bug excrement (Maral, 2021). The infection reduces both photosynthesis and respiration processes, and also causes aesthetically displeasing injured leaves. As a result leaves may drop early (Lodos, 1982; Mahmoud \& Muhammed, 1983; Vergnani \&
Caruso, 2008). (Shen et al., 1985) indicated that S. pyri were active in early April as the spring was being mild, they laid their eggs on the underside of the leaves. In Turkey, Tazcan and Önder (2003) found that pear lace bug is an important pest of fruit trees belongs to family Rosaceae, especially both apple and cherry. Due to their soft body the pest overwinters as adult, and three generations have been found in Marmara Region (Lodos, 1982; Gulpercin \& Önder, 1999; Tazcan \& Onder, 2003; Aysal \& Kivan, 2008, Maral, 2021). In Syria S. pyri was found feeding on Pyracantha angustifolia (Franch.) which is narrow leaf firethorn shrubs, the adult insects were collected from several fruit orchards, containing narrow leaf firethorn shrubs as hedge plants (Diab, et al, 2018). In Iraq investigations have been reported that pear trees are most infected than other ornamental trees with S. pyri (Mahmoud \& Muhammed, 1983; Al. Mallah \& Al-Obadi, 2007; Al. Mallah $\&$ Al-Obadi, 2009). The aim of the investigation to study seasonal fluctuation of the lace bug $S$. pyri. on pear trees and as a result to find out effect some weather factors on their population density and natural infestation, in order to detecting the time of chemical control. 


\section{MATERIALS AND METHODS}

From the private orchard planted with numerous fruit trees located in Kasnazan district (10 Km east of Erbil city), five pear trees more or less similar in size and age (non-treated with insecticides) were selected. Weekly visiting to orchard were carried out along growth seasonal period from March till December for the two years 2012-2013. Direct visual inspection of sap sucking insects on the pear trees was done, and the samples were brought to lab. Collected species were identified on the basis of external morphology with the help of available literature and keys (Muhammed, 2020; Castner, 2000; Triplehorn and Johnson, 2004).

To study the seasonal fluctuation of lace bug, samples of 50 leaves were collected at random from the selected trees (10/tree) and kept inside a nylon bag and closed, then bring to the lab and both nymph and adult were counted and recorded. Population counts of lace bug S. pyri made on both surfaces of the leaves and recorded weekly during the period from April till mid of November in the two successive years. Average of the temperature and relative humidity were obtained from the Meteorological directories of Erbil.

Data analysis was performed applying Graphpad Prizm (version 8). Comparisons among the seasons were done via using One way-ANOVA, while simple Pearson's correlation were used for finding the positive and negative correlation between the insects' activities and various environmental factors. Data have been rearranged seasonally (March, April, May as season 1; June, July, August as season 2; September, October, November as season 3/ year) in order to explain the effect of temperature on the activity of insect during each year. $\mathrm{P}<0.05$ was considered as statistically significant differences or correlation between variables. The data are represented as Mean and Standard error.

\section{RESULTS AND DISCUSSION}

The data in table (1) represent the five species of sap sucking insects recorded on the pear trees during the period from April till October of both year 2012, 2013 in orchards within Erbil city.

Table (1): Sap sucking insects infected pear trees

\begin{tabular}{llcc}
\hline \multicolumn{1}{c}{ Pest species } & Family & Duration & Plant part infected \\
\hline Dysaphid pyri (Boy.) & Homoptera & April-June & New leaves opening \\
\hline Apodiphus amygdali (Germar) & Hemiptera & June-October & Leaves \& Stem \\
\hline Mustha spinulosa(Lefebvre) & Hemiptera & June-October & Main Stem \\
\hline Siphoninus phillyreae (Haliday) & Homoptera & April-June & Underside of leaves \\
\hline Stephanitis pyri (F.) & Hemiptera & April-October & Underside of leaves \\
\hline
\end{tabular}

\section{Seasonal fluctuation of $S$. pyri:}

Results recorded in Table (2\&3) represent the population density and seasonal fluctuation of the lace bug during the years 2012 and 2013.

In 2012, it is clearly shown that the infestation was represented by relatively low numbers during the first three months (April, May and June). Thereafter the numbers increased to reach the maximum during the mid of August 13.88 (694 individuals /50 leaves), after which it decreased gradually and disappeared completely through the second week of November.

It could be pointed out that the infestation in year 2013 started in the fourth week of April (after three weeks in contrast to the former year) with more numbers (0.16). The peak 11.4 (570 individuals $/ 50$ leaves) was reached during the third week of August, after that the insects were gradually decreased then disappeared completely in the first week of November.

The obtained results indicated that the month of August was considered as the suitable period of the insect activity during which the gross population was noticed. This point may be taken in consideration to detect the suitable time of insecticidal control. Observation during the both seasons in the farm, showed that the females were active in laying their eggs on the underside of the leaves throughout last week of April and the first fortnight of May. 
Table (2): Population density (mean) of S. pyri (nymphs and adults) population on pear leaves together with the temperature and relative humidity during growth year 2012 within Erbil city.

\begin{tabular}{|c|c|c|c|c|}
\hline \multicolumn{2}{|c|}{ Date } & \multirow{2}{*}{$\frac{\text { Mean No. of Lace bug }}{0.06}$} & \multirow{2}{*}{$\frac{\text { Temp. }}{18.30}$} & \multirow{2}{*}{$\begin{array}{l}\text { R.H. } \\
44.54\end{array}$} \\
\hline April & $1^{\text {st }}$ week & & & \\
\hline & $2^{\text {nd }}$ week & 0.04 & 19.50 & 46.36 \\
\hline & $3^{\text {rd }}$ week & 0.02 & 20.03 & 48.25 \\
\hline & $4^{\text {th }}$ week & 0.12 & 21.70 & 53.23 \\
\hline \multirow[t]{4}{*}{ May } & $1^{\text {st }}$ week & 0.04 & 23.36 & 42.71 \\
\hline & $2^{\text {nd }}$ week & 1.00 & 27.09 & 47.14 \\
\hline & $3^{\text {rd }}$ week & 0.86 & 27.06 & 48.88 \\
\hline & $4^{\text {th }}$ week & 0.50 & 33.25 & 30.13 \\
\hline \multirow[t]{4}{*}{ June } & $1^{\text {st }}$ week & 0.50 & 30.14 & 38.14 \\
\hline & $2^{\text {nd }}$ week & 0.36 & 32.86 & 35.57 \\
\hline & $3^{\text {rd }}$ week & 0.58 & 33.50 & 29.63 \\
\hline & $4^{\text {th }}$ week & 2.98 & 34.00 & 28.13 \\
\hline \multirow[t]{4}{*}{ July } & $1^{\text {st }}$ week & 2.48 & 32.86 & 24.00 \\
\hline & $2^{\text {nd }}$ week & 1.70 & 35.44 & 29.00 \\
\hline & $3^{\text {rd }}$ week & 2.00 & 33.00 & 29.13 \\
\hline & $4^{\text {th }}$ week & 1.90 & 36.63 & 23.63 \\
\hline \multirow[t]{4}{*}{ Aug. } & $1^{\text {st }}$ week & 4.48 & 36.43 & 23.00 \\
\hline & $2^{\text {nd }}$ week & 11.00 & 33.75 & 27.75 \\
\hline & $3^{\text {rd }}$ week & 13.90 & 33.38 & 24.38 \\
\hline & $4^{\text {th }}$ week & 10.30 & 33.88 & 26.88 \\
\hline \multirow[t]{4}{*}{ Sept. } & $1^{\text {st }}$ week & 9.90 & 33.64 & 23.86 \\
\hline & $2^{\text {nd }}$ week & 5.28 & 31.64 & 29.71 \\
\hline & $3^{\text {rd }}$ week & 4.10 & 29.21 & 29.92 \\
\hline & $4^{\text {th }}$ week & 2.40 & 28.87 & 31.24 \\
\hline \multirow[t]{4}{*}{ Oct. } & $1^{\text {st }}$ week & 7.90 & 27.02 & 33.00 \\
\hline & $2^{\text {nd }}$ week & 5.68 & 27.75 & 35.32 \\
\hline & $3^{\text {rd }}$ week & 6.18 & 26.95 & 36.69 \\
\hline & $4^{\text {th }}$ week & 2.64 & 26.03 & 38.01 \\
\hline
\end{tabular}

Table (3): Population density (mean) of $S$. pyri (nymphs and adults) population on pear leaves together with the temperature and relative humidity during growth year 2013 within Erbil city.

\begin{tabular}{ccccc}
\hline & Date & Mean No. of Lace bug & Temp. & R.H. \\
\hline April & 3rd week & 0 & 18.80 & 46.56 \\
\hline May & 4th week & 0.16 & 19.27 & 49.86 \\
\hline & 1st week & 0.20 & 24.36 & 42.71 \\
\hline 2nd week & 0.70 & 27.09 & 47.14 \\
\hline June & 3rd week & 1.00 & 25.24 & 52.57 \\
\hline & 4th week & 0.76 & 33.86 & 31.71 \\
\hline 1st week & 0.98 & 30.60 & 38.86 \\
\hline 2nd week & 0.58 & 31.10 & 32.86 \\
\hline 3rd week & 0.98 & 33.40 & 27.43 \\
\hline 4th week & 1st week & 3.50 & 34.33 & 30.71 \\
\hline & 2nd week & 2.22 & 36.04 & 27.29 \\
\hline 3rd week & 1.48 & 33.29 & 31.86 \\
\hline & 4th week & 1.78 & 36.93 & 30.00 \\
\hline
\end{tabular}


Journal of University of Duhok, Vol. 24, No.2 (Pure and Eng. Sciences), Pp 29-35, 2021

\begin{tabular}{|c|c|c|c|c|}
\hline Aug. & 1st week & 5.04 & 35.64 & 28.71 \\
\hline & 2nd week & 10.6 & 34.90 & 31.86 \\
\hline & 3rd week & 11.4 & 34.31 & 29.57 \\
\hline & 4th week & 9.88 & 34.91 & 34.43 \\
\hline \multirow[t]{4}{*}{ Sept. } & 1st week & 8.88 & 35.06 & 28.71 \\
\hline & 2nd week & 6.42 & 30.44 & 33.00 \\
\hline & 3rd week & 3.98 & 29.63 & 34.00 \\
\hline & 4th week & 2.52 & 28.67 & 35.57 \\
\hline \multirow[t]{4}{*}{ Oct. } & 1st week & 5.00 & 28.31 & 30.43 \\
\hline & 2nd week & 3.90 & 27.30 & 37.43 \\
\hline & 3rd week & 4.20 & 23.33 & 39.57 \\
\hline & 4th week & 1.78 & 23.70 & 35.86 \\
\hline Nov. & 1st week & 0 & 19.43 & 38.29 \\
\hline
\end{tabular}

Statistically, results indicated that the correlation between the temperature and the total mean numbers of lace bug was positively significant $(\mathrm{P}<0.001)$ through the two successive years (fig. 1). It could be pointed out that the insect activity increased by rising of temperature during that period of investigation. Thus it was considered that temperature was a factor of importance which affected the insect activity.

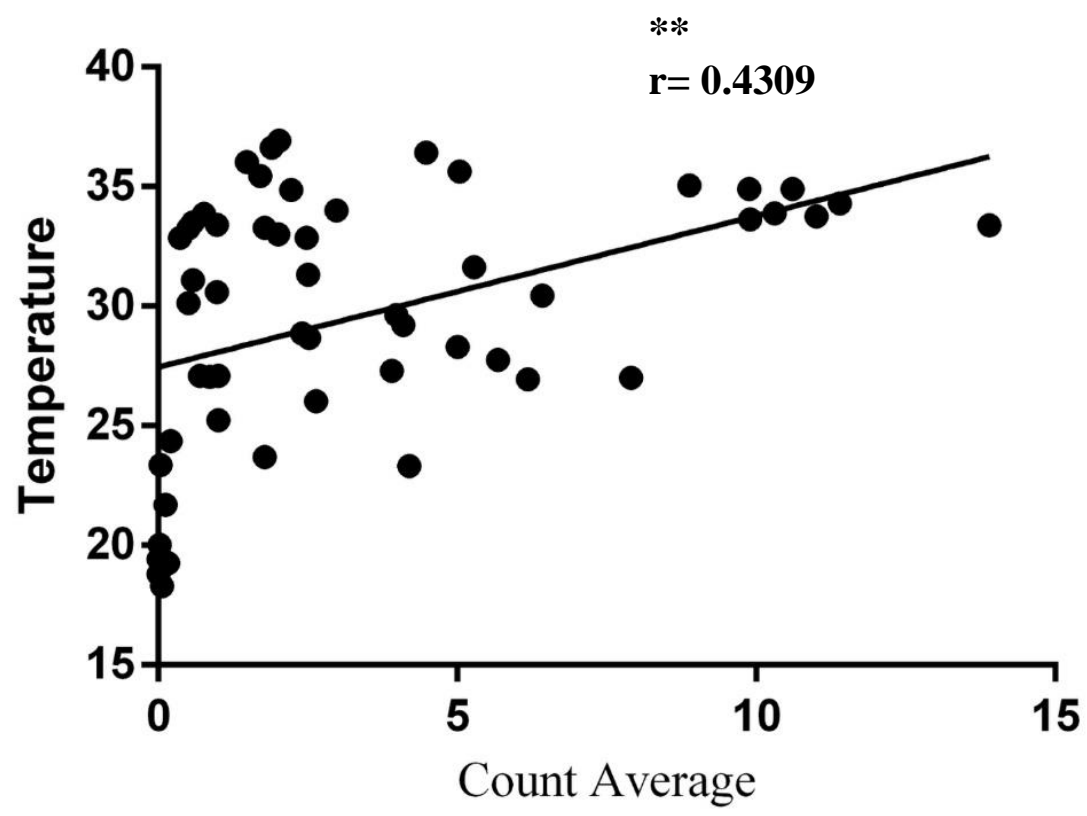

Fig. (1): Correlation between mean numbers of lace bug with temperature during the two years 2012-2013 growing.

The relative humidity during the study period showed highly effect on the insect activity. The value of correlation indicated negative significant correlation $(\mathrm{P}<0.0001)$ during the two successive years (fig. 2). It can be noticed therefore that the decrease in relative humidity, was accompanied with increase of insect population. 


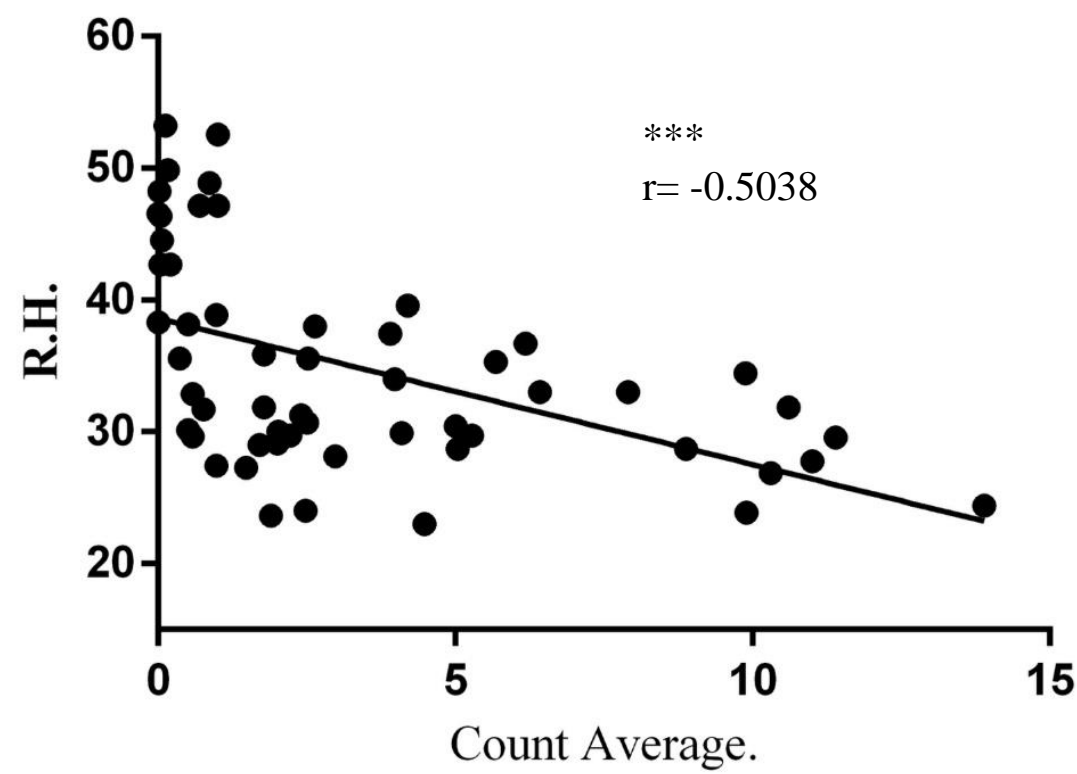

Fig. (2): Correlation between mean numbers of lace bug with relative humidity during the two years 2012-2013 growing.

Figure (3) reported the highest number of lace bugs in season 2 which was positively correlated with the high temperature in that season as mentioned in the previous figure
(Figure 1). The number of lace bugs was found to be near to zero in the cold season (Season 1). The difference between the seasons were statistically significant at $\mathrm{p}<0.05$.

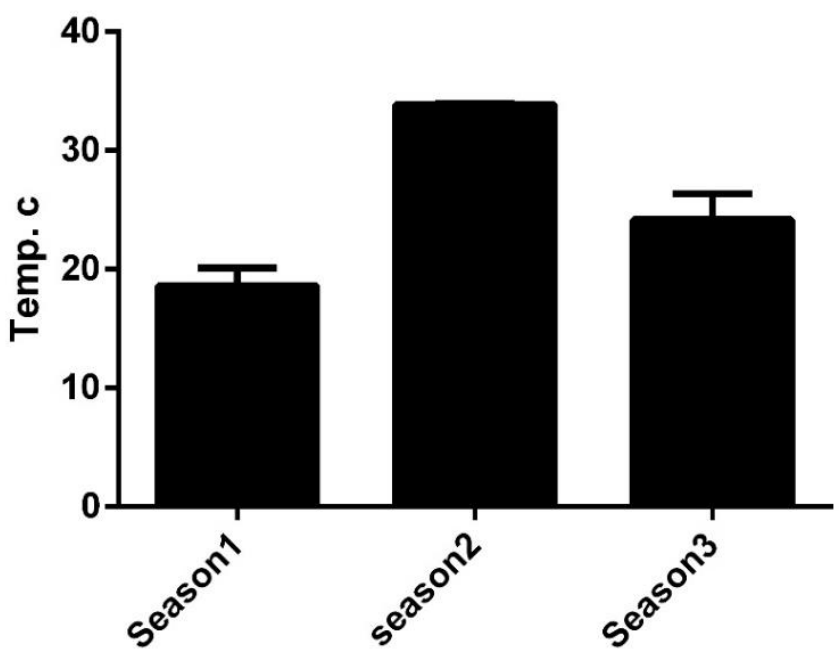




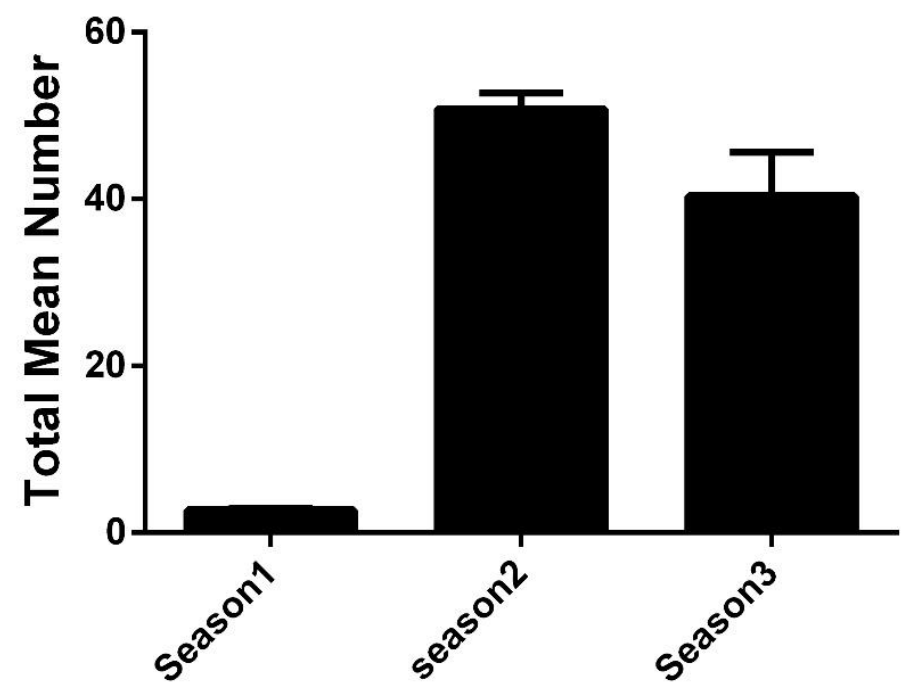

\section{B}

Fig. (3): Correlation between total mean numbers of lace bug and three seasons during the two years 2012-2013 growing. $A=2012 \quad B=2013$

\section{Acknowledgment}

I would like to thank Dr. Goran Q. Othman (Erbil Polytechnic University) for their help in analyzing the data statistically.

\section{REFERENCES}

Silva, G. J.; Souza, T. M.; Barbieri, R. L.; Costa de Oliveira, A. (2014). Origin, Domestication, and Dispersing of Pear (Pyrus spp.). Hindawi Publishing Corporation, Advances in Agriculture. P 1-8.

Regional Statistics Organizing (RSO) (2008). A survey of different Fruit trees in Kurdistan Region. Report prepared by Ministry of Planning (agricultural sector), Kurdistan region. Iraq.

Önder, F and Lodos, N. (1983) Preliminary list of Tingidae with notes on distibution and importance of species in Turkey. Ege University Press, Izmir

Barta, M. and Bibeň, T. (2016). Stephanitis takeyai and $S$. rhododendri (Heteroptera: Tingidae) in Slovakia: first record and economic importance. Journal of Plant Protection Research, 56: 193-198.

https://doi.org/10.1515/jppr-2016-0022

Kivan, M. and Aysal, T. (2011). Adult survival rate and oviposition preference of Stephanitis pyri (F., 1775) (Heteroptera: Tingidae) on different plant species. Turkish Journal of Entomology, 35: 169-178.

Hradil, K.; Psota, V. and Štastná, P. (2013). Species diversity of true bugs on apples in terms of plant protection. Plant Protection Science, 49: 73-83.

https://doi.org/10.17221/30/2012-PPS
Muhammed, S. H. (1995). Survey of sap sucking insect on some fruit trees. M.Sc. thesis, college of Education, University of Salahaddein.

Şahin, A.K.; Özpinar, A.; Polat, B. and Sakaldaş, M. (2009). Population density of pear lace bug (Stephanitis pyri (F.), Heteroptera: Tingidae) at different aApple cultivars in Çanakkale Province. Agricultural Science Research Journal, Ankara University, 2: 119-122.

Maral, H. (2021). Effect of spinosad, azadirachtin and kaolin on Stephanitis pyri (Fabricius, 1775) (Hemiptera: Tingidae) under laboratory conditions. Turkish Journal of Entomology (45)1: 87-97.10- Lodos, N. (1982). Turkiye Entomolojisi II (Genel, Uygulamali ve Faunistik). Ege University Press, Izmir.

Mahmoud, T. R and Mohammed, M. A. (1983). Seasonal abundance of Stephanitis pyri on pear trees in Moosul region, Iraq. Iraqi Journal of Agricultural sciences (Zanco), 1 (2), P. 81.

Vergnani, S. and Caruso, S. (2008). Investigation on the efficacy of different products for the control of Stephanitis pyri in an organic pear orchard during the two-year period 2004-5. Pages 496-499. In: $16^{\text {th }}$ IFOAM Organic World Congress, Modena, June 16-20, Italy.

Al. Mallah, N. M. and Al-Obadi, A. K. (2007). The effect of pear variety, numbers of lace bug Insects and some other environmental factors on the damage area and percentage resulting from Infection by the lace bug insect in Mosul city-Iraq). Mesopotamia Journal of Agriculture 35 (4).

Al. Mallah, N. M. and Al-Obadi, A. K. (2009). The role of some secondary compound on the 
Susceptibility of some pear varieties to infection by Pear lace bug Stephanitis pyri (f.) (tingidae: hemiptera). Mesopotamia Journal of Agriculture 37 (4).

Shen, H.W., Wu, W.J. and Yang, P. S. (1985). The biology of the lace bug, Stephanitis pyrioides (Scott). Yen chiu pao kao (Memoirs of the College of Agriculture, National Taiwan University, (25) 1, 143-154.

Gulpercin, N. and Önder, F. (1999). Bornova koşullarında Stephanitis pyri (F.) (Heteroptera: Tingidae)'nin biyolojisi ve dogal düşmanları üzerinde çalışmalar. Türkiye Entomoloji Dergisi, 23: 51-56.

Tazcan, S. and Önder, F. (2003). Faunistical studies in ecological cherry orchards in Izmir and Manisa provinces of Turkey: an evaluation on the species of heteroptera. J. of aegean Agr Res. Inst.

Aysal, T. and Kivan, M. (2008). Development and population growth of Stephanitis pyri (F.) (Heteroptera: Tingidae) at five temperatures. Journal Pest Science, 81: 135141.https://doi.org/10.1007/s10340-008-01989

Al. Mallah, N. M. and Mohammed, M. A. (1988). Seasonal abundance of leaf rolling aphid Dysaphis pyri (Boy.) (Homoptera: Aphididae) on apple and pear trees in orchard of the college of Agricultural and Forestry in Hammam Al-Alil. Arab Journal Plant protection, Vol (6):71-75.

Anonymous (2016). Pear bedstraw aphid-Inra. (http://www7.inra.fr/hyppz/

RAVAGEUR/6dyspyr.htm) (Accessed 5 May 2016).
Schuh, R.T. and Slater, J. A. (1995). True bugs of the world. Cornell University Press, Ithaca, NY: 336.

Muhammed, S. H. and Al-Iraqi, R. A. (2010). The biology of the stink bug Apodiphus amygdali (Germar) (Hemiptera: Pentatomidae). Mesopotamia Journal of Agriculture 38 (1): 1$53 \mathrm{pp}$.

Bellows, T. S.; Paine, T. D.; Arakawa, K. Y.; Meisenbacher, C.; Leddy, P. and Kabashimo, J. (1990). Biological control sought for ash whitefly. California Agriculture 44(1): 4-6.

Drake, C. J. and Ruhoff, F. A. (1965). Lace bugs of the World - A Catalog (Hemiptera: Tingidae). Smithsonian Institution, Washington D.C. United States National Museum Bulletin 213. $634 \mathrm{pp}$.

Diab, N.; Al-Jouri, E.; Daher-Hjai, N. and A. Almanoufi (2018). First record of pear lace bug Stephanitis pyri (F. 1775) on narrow leaf firethorn shrubs Pyracantha angustifolia (Franch.) C.K. Schneid., in Syria. Arab Journal of Plant Protection, 36(2): 94-97.

Muhammed, S. H. (2020). Seasonal Fluctuation of Stink Bug Mustha Spinulosa (Lefebvre, 1831) (Hemiptera, Pentatomidae) on Some Trees in Erbil City. Bulletin Iraq Natural History Museum, 16(2):151-160

Castner, J. L. (2000). Photographic atlas of Entomology and guide to insect identification, sixth edition. Feline press, $176 \mathrm{pp}$.

Triplehorn, C. A. and Johnson, N. F. (2004). Borror and Delong's Introduction to the Study of Insects, seventh edition. Thomson Brooks/Cole. 868pp. 